\title{
Influence of Zen Buddhism on Buddhadasa Bhikkhu
}

\author{
Phramaha Surachai Phutchu ${ }^{1}$,Winit Pharcharuen ${ }^{2}$, Sirikanda Khamkaew $^{3}$,Noppadon Inping ${ }^{4}$ \\ ${ }^{1}$ Independent Scholar, Wat Suthattheppawararam, Bangkok Thailand \\ ${ }^{2}$ School of Administrative Studies, Maejo University, Thailand \\ ${ }^{3,4}$ Mahachulalongkornrajavidyalaya University, Phayao Campus Thailand \\ Email: ${ }^{1}$ sura_chai_2524@ hotmail.com, ${ }^{2}$ winit.phacharuen@gmail.com, ${ }^{3}$ toyingsnoopy@gmail.com, ${ }^{4}$ noppadonin003@gmail.com,
}

\begin{abstract}
Zen is one of Mahayana Buddhism which is propagated in China, Korea, Japan, Vietnam, and many counties in the West. In Thailand Zen was known widespread because of Buddhadasa Bhikkhu's translated works. Furthermore, he has studied and applied its teachings for developing Thai society through establishing Suan Mokkhabalarama. There is the center of study and practice the Dhamma which reflects the concept of Zen, such as Spiritual Theater, Curved Stone Court, Natural Uposatha, Dhamma Ships, Avalokiteshavara Bodhisattva's Statue, and Nalike Pond. These places are strongly influenced by Dhamma puzzle of Koan and Zen garden arrangement which emphasize the cultivation of wisdom, living simple and in harmony with nature. In the term of Dhamma teaching Buddhadasa Bhikkhu mixes the principle of Theravada and Zen teachings properly, that is the principle of working with empty mind.
\end{abstract}

Keywords

Zen Buddhism, Buddhadasa Bhikkhu, Suan Mokkhabalarama

Article Received: 10 August 2020, Revised: 25 October 2020, Accepted: 18 November 2020

\section{Introduction}

Zen is one sect of Mahayana Buddhism. Many people around the world, in Japan, China, Korea, and Vietnam, believe in Zen. In the beginning, Zen originated in India and since the Buddha's life time spread to China and Japan. Zen in these countries has divided into two sects, i.e. Rinzai and Soto. Both of them have roles to develop the different aspects of societies and countries. Especially, Zen in Japan has played a role to create the Japanese cultures, such as Zen garden, tea ceremony, and samurai. Zen has three instruments of Satori or enlightenment as followings: Koan, Zazen, and Mondo. These are called Upaya Kosala Theory in hermeneutics which means the skillful method to teach. Its result is to attain the Buddhahood. These are the identification of Zen to get supramundane wisdom or Lokuttara Paññā.

Furthermore, Zen has mundane wisdom or Lokiya Paññā which is suitable to apply for developing worldly states. It might say that Japanese society is not based on Shinto only but also on Zen Buddhism to be the ideal or philosophy of Japanese cultures. Many European countries also practice Zen, such as Plum village in France where Ven. Thich Nhat Hanh has been teaching Rinzai Zen and propagating around the world, including Plum Village in Pakchong, Nakhon Ratchasima Province, Thailand. In the USA Daisetz Teitaro Suzuki has propagated Zen as a lecturer at American University since 1951. Even though Steven Paul Jobs, the co-founder of Apple Inc. has spent his life following Zen philosophy through reading 'Zen Mind, Zen Beginner's Mind' written by Shunryu Suzuki, a master of Soto sect.

\section{Zen Buddhism In Thailand}

In Thailand many people study Zen and apply the lifestyle. One of them is Ven. Buddhadasa Bhikkhu who founded Wat Than Nam Lai, well-known as Suan Mokkhabalarama in
Suratthani Province, southern Thailand. His lifestyle seems to be Zen Buddhism, even though he is a Theravada monk. His monastery appears as Zen style. He has also translated many Zen books, such as the Platform Sutra of Huineng who was the $6^{\text {th }}$ Patriarch, the Zen Teaching of Huang Po, and Zen tales. For practicing meditation, many Thai monks have the same way of Zen tradition, such as Luangpu Dune Atulo, Wat Burapharam in Surin Province and Luangpor Teean Cittasubho, Wat Sanamnai in Nonthaburi Province. Luangpu Dune preaches the teachings about 'the four noble truths' in the following:

On the first day of rain retreat in 1956 one senior monk of the meditation tradition came to pay his respect to Luangpu. After giving him the instruction and number of teachings on profound matters, Luangpu summarized the four noble truths as follows: "The mind sent outside is the Origination of Suffering (Samudaya). The result of the mind sent outside is Suffering (Dukkha). The mind seeing the mind is the Path (Magga). The result of the mind seeing the mind is the Cessation of Suffering (Nirodha).” [1]

Whereas Luangpu Dune preaches the noble truths briefly, Luangpor Teean preaches the method to develop awareness which has fifteen steps to move both hands while sitting cross-legged. It is the way to follow the four foundations of mindfulness (Sati Patthana). While moving each hand meditator has to be aware of moving. This method has no recited words and no need to close the eyes. Because of this practice, his teachings are compared with Huineng, the $6^{\text {th }}$ patriarch of Zen. Both of Luangpor Teean and Master Huineng emphasize on simplicity and do not pay attention to ritual more than practicing. In addition, they have the same color of robes, i.e. dark grey which are similar to color of the ground. Hence, Luangpu Teean is known as master of practicing mindfulness by considering body movement and thought.

By the technical words, above masters teach in the same term of mind, for example Luangpu Dune talks about 'Mind 
is Buddha,' Master Huineng talks about 'Original Mind,' whereas Buddhadasa Bhikkhu talks about 'Empty Mind.' However, the details of teachings of Thai masters might not relate to Zen Mahayana directly. It is because the way to practice is the difference in concept and it depends on cultures, sects, and their own schools. For example, Theravada emphasizes on self-enlightenment first, and then helps people to attain it. But Mahayana emphasizes on helping people as Bodhisattva first. However, Zen by original is Mahayana but the way to practice seems like Theravada which tries to attain Satori himself first. Moreover, Zen is an applied school of Mahayana because it is related to new society to where spreads its teachings. For example, Zen in Japan is different from China and India because of its adaptation to these cultures. So, Buddhadasa Bhikkhu has said Zen is the developed Buddhism where it propagated the teachings. [2] In this article I would like to consider the concept of Zen according to Buddhadasa Bhikkhu which appears in Suan Mokkhabalarama.

\section{Background of Buddhadasa Bhikkhu}

Buddhadasa Bhikkhu has the name which the King bestowed as Phra Dhamma Kosacariya, but he still call his own name as Buddhadasa, according to poetry that he wrote himself, the meaning is: I offer this life and body to the Buddha, the Buddha is my master, I am the Buddha's servant. Thus, I am called 'Buddhadasa.' He is a reformer who needs to develop the community of monkhood at that time. After leaving the monastery in Bangkok where he studied Pāli, he established a monastery in his hometown. This monastery was originally named Wat Traphangjik, an abandoned monastery located at Phumriang Village, Phumriang Sub-district, Chaiya District, Suratthani Province. He reconstructed it with his younger brother and four to five people and came to stay on Vesak Day, $12^{\text {th }}$ May, 1932. This location had many wrightia religiosa benth trees, so he gave the monastery's name as Suan Mokkhabalarama. Actually, these trees called Mok in Thai which is synonymous with Mokkha in Pāli and means liberation. Thus, this monastery represents the grove of the power of liberation.

In 1941 he moved to the new place which was called Khao Buddh Thong, meant 'Golden Buddha Hill.' It had natural Uposatha (Ordination Hall), the center of monastery which had over one hundred and twenty acres of whole land. Officially, it was known as Wat Than Nam Lai, meant that 'Monastery of the Flowing Stream' that ran down form Nang E Hill. But most of people knew as Suan Mokkh, meant 'the Garden of Liberation.' In 1989 he established Suan Mokkh International Dhamma Hermitage which was opposite side of the highway and approximately went 1.5 kilometer in distance as following map:

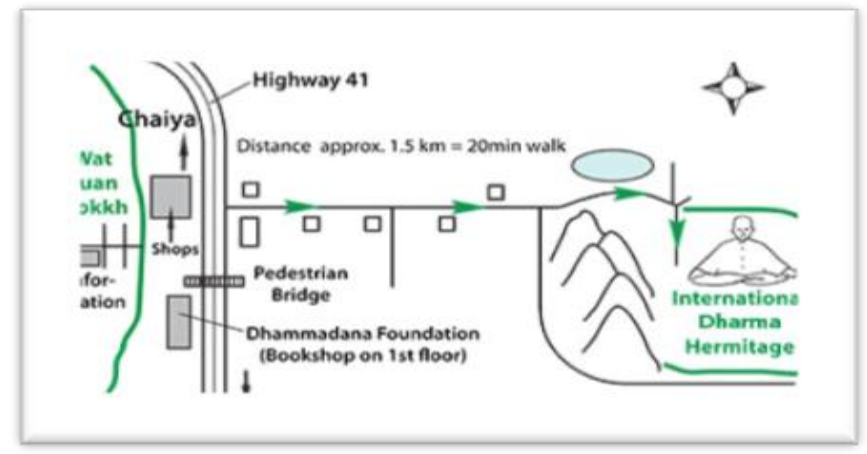

Fig. I: Map of Suan Mokkh International Dhamma Hermitage [3]

A sign at the monastery explains the meaning of Suan Mokkhabalarama in the following: 'A Mok Tree and a Phla Tree: tree whose names identify Suan Mokkhabalarama; mokkha means liberation, bala means power, and arama means shading grove; Suan Mokkhabalarama means the Grove of the Power of Liberation.'

\section{Construction within Suan Mokkhabalarama}

\section{Curved Stone Court}

A lot of signs show the meaningful places at monastery, one of them is Curved Stone Court which has an explanation that 'it is one symbol of Suan Mokkh which is most suitable for practicing Dhamma; it is reflection of Buddhadasa Bhikkhu's ideal on what he needed people to practice at Suan Mokkh through talking with a tree and stone and learning conditioned things (Sangkhata Dhamma) and unconditioned things (Asangkhata Dhamma); nowadays here is the place for demonstrating alms giving, chanting, preaching, and meditating; all activities will start at 4:30 a.m.'

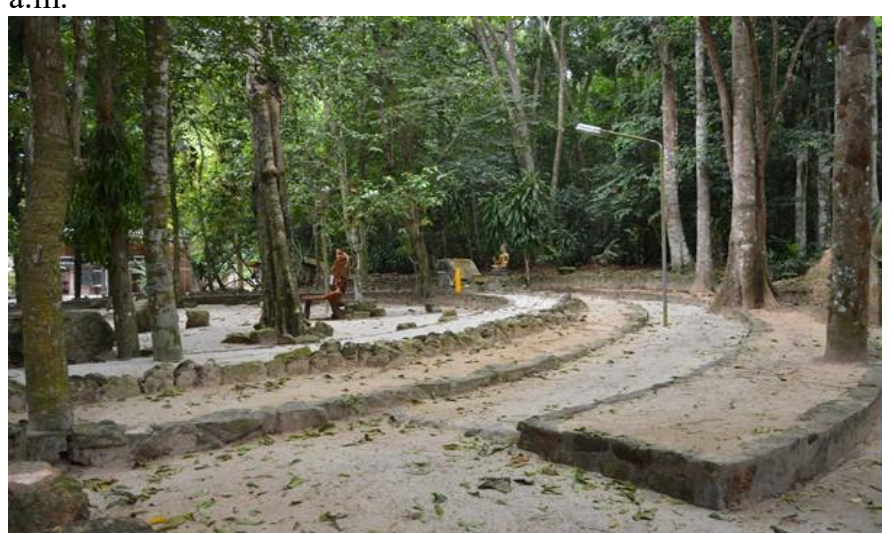

Fig. II: Curved Stone Court [4]

\section{Spiritual Theater}

If we walk inside the monastery and reach the Spiritual Theater, a dominant picture of distributing the Dhamma eyes is shown on the front wall of theater building. It is a Dhamma puzzle that explained by Buddhadasa Bhikkhu's poetry in following translation: 'Spiritual Theater is a special work, it is for starting a love of Dhamma to people in mundane era and protecting themselves by facing Dhamma in this era. For this reason, I collect fantastic Buddhist arts 
from different periods and countries for cultivating wisdom of people who come to get tasting of Dhamma instead of sexuality. If Dhamma comforts them to feel good, they are able to escape from sexuality and prefer a beautiful monastic life which is the correct way of Dhamma.'

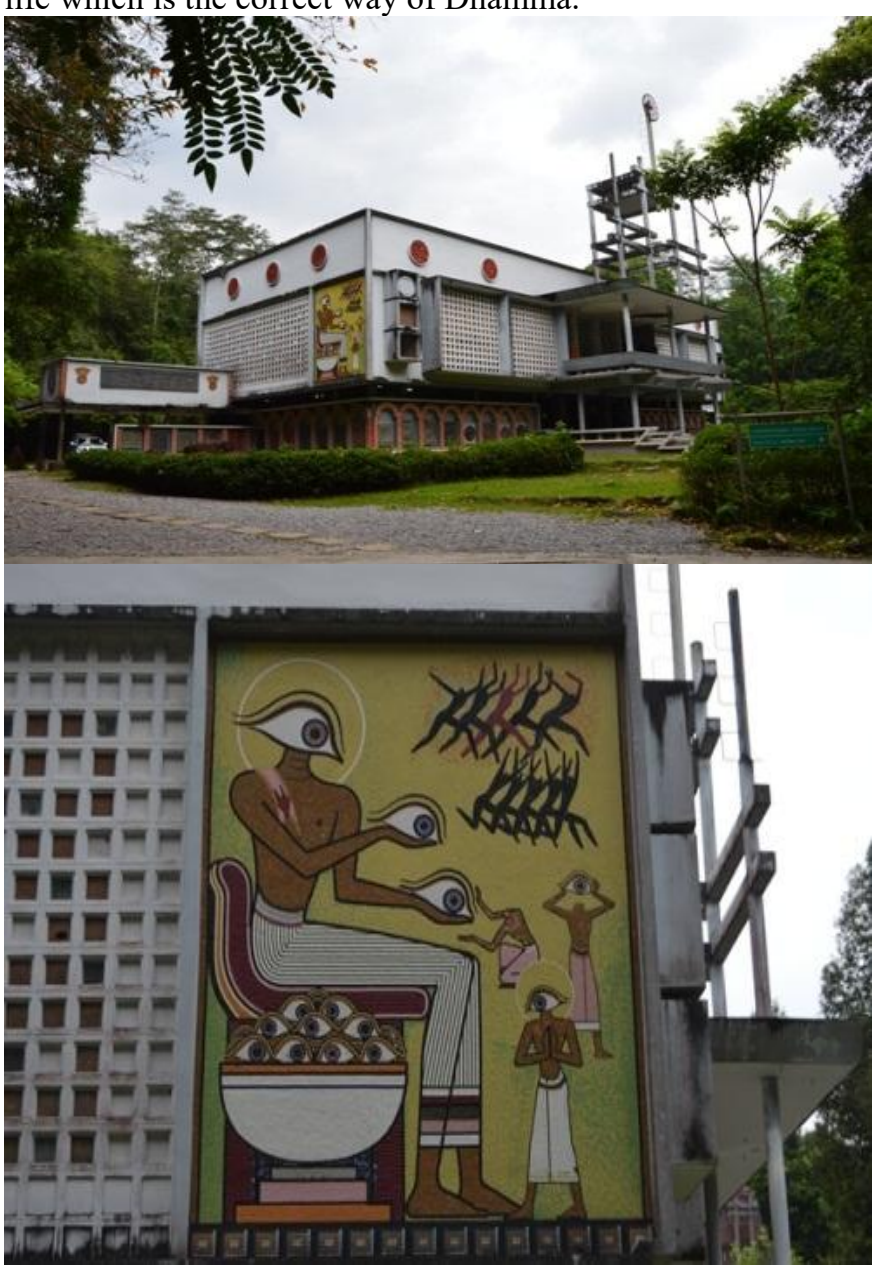

Fig. III: Spiritual Theater and Picture of Distributing the Dhamma Eyes [5]

Spiritual Theater is a new tendency in Buddhist architecture towards creating non-hierarchical sites for the teaching of Buddhist doctrine through aesthetic experience and leisure practices. [6] It is approximately ten meters in width and one hundred meter in length. Outside wall of building is curved by set of the Buddha's story and beside of building is arranged by group of rocks. It has two floors. On the $1^{\text {st }}$ floor it has seven groups of Dhamma puzzle paintings as follows: 1) paintings of butterfly, dog, and deity that show around pillars of the building; 2) paintings form Monk Emanuel Sherman, American Zen Master that hang on the inner wall; 3) paintings of world and philosophy that hang on the inner wall; 4) paintings of proverbs around the pillars; 5) paintings of tales about the Dependent Origination (Paticcasamuppāda) that place on the stage in the middle of building; 6) paintings of Kaya Nagara (city of body) that hang on the inner wall; and 7) paintings of Zen that hang on the inner wall.

On the $2^{\text {nd }}$ floor it has interior balcony to watch three groups of Dhamma puzzle paintings and pictures as followings: 1) pictures of Buddhadasa Bhikkhu spent his time in India that hang on a balcony; 2) paintings that concern with desire, hatred, and delusion on the wall; and 3) paintings about mustache of turtle and horn of rabbit on the beam. In addition, it has pictures and teaching instruments as followings: 1) picture of Tibetan Paticcasamuppada (Wheel of Becoming) on the wall; 2) picture of emptiness on a balcony; 3) symbol of Triple Gem on a balcony; and 4) a small room for recording.

All paintings or pictures are simply arranged. Some have explanation as poetry. First painting is dominant at the front entrance of building named 'sound of flute has returned to bamboo forest.' Buddhadasa Bhikkhu explained in poetry as following translation: 'Sound of flute has returned to bamboo forest. Please think about this message, bamboo that is cut to make a flute and have a good flute sound. Sound is returned to bamboo, it is as strong as it is fluted, like steam rising from the sea becomes a cloud and rains back to the sea. Like a desire that carries people to the world, when it ceases the power of birth, it runs into land of purity, do not wander somewhere. A state of disorder has come to emptiness. It is no way to go anywhere. In final, it ceases what has been done. So ceasing (emptiness) is essential of the Dhamma.' [7]

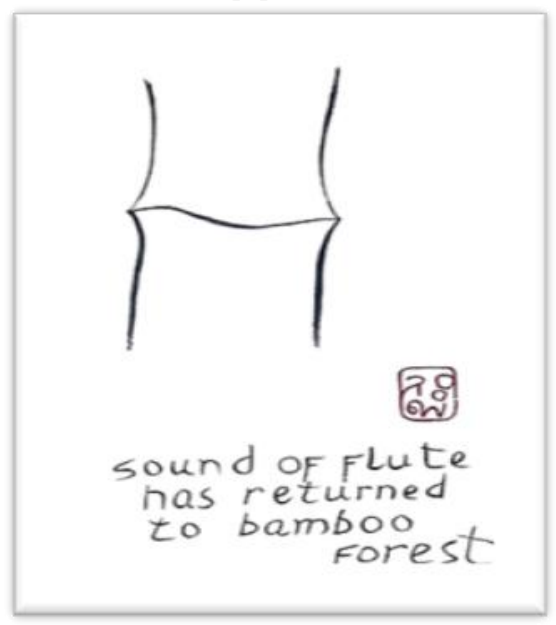

Fig. IV: Painting of Sound of Flute [8]

\section{Dhamma Ships}

The back side of Spiritual Theater has two sailing ships. The former one is called Dhamma Varinava Issarakul Naleumit. It is an explanation that 'it is like a ship for crossing the cycle of birth and death (samsara) to escape from sufferings, crossing from sufferings toward happiness and from ignorance toward wisdom. On the ship it has Zen garden, a tower of bell at the head, and Sanchi pagoda at the top floor of the tower. In the bilge ship it contains water as the tang.' The latter ship is called Dhamma Varinava. It is an explanation that 'in the bilge ship it is a tang of raining. Upper floor of ship is an ordinary hall for meeting, preaching while raining. At the head of ship is located the library named Mokkha Pannalai.'

\section{Body Burning Memorial}

Beside of Spiritual Theater has pathway going up to Uposatha or ordination hall around one hundred and fifty meters. When reaching this place, it has a wide area which is called Khao Buddh Thong. In the front part of area it has a big marble pillar about three meters in height and water drop 
at the top. It has four aspects and each one is fifty in width and one and fifty meter in length. Each aspect is written in four different languages, if walking along clockwise direction, i.e. Pāli, English, Thai, and Chinese. In the pillar it appears the messages as followings: here is the cremation of Buddhadasa Bhikkhu (Phra Dhamma Kosacariya), corresponding on $28^{\text {th }}$ September, 1993 on Tuesday, the $13^{\text {th }}$ of waxing moon in the $10^{\text {th }}$ of lunar month.'

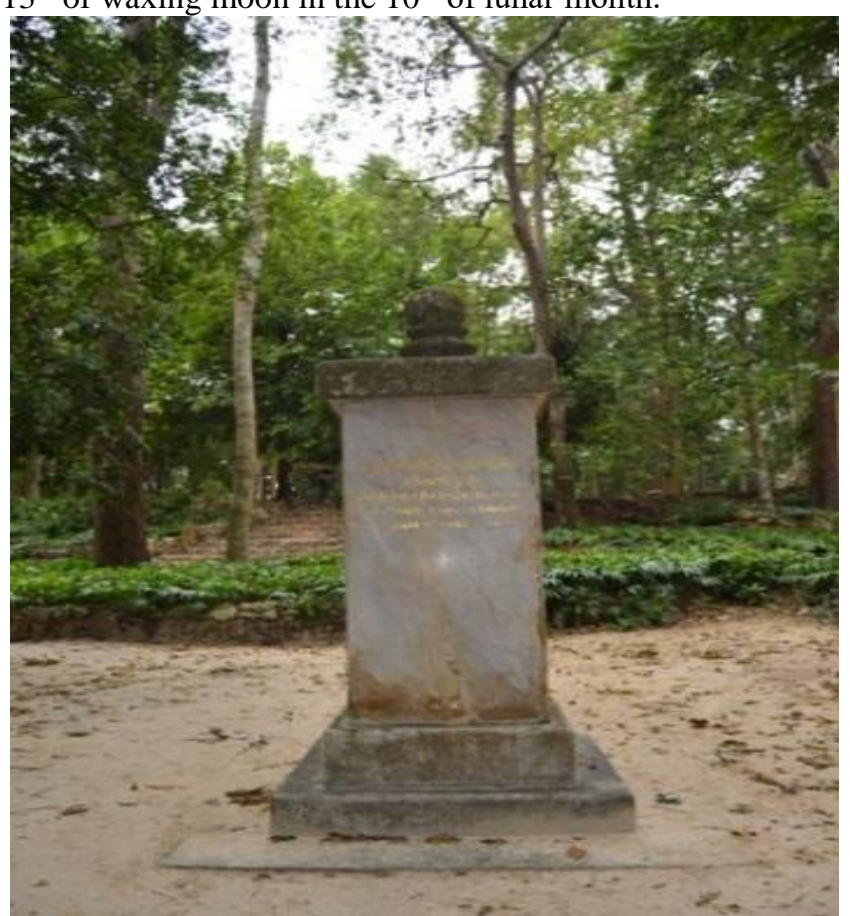

Fig. V: Body Burning Memorial [9]

Buddhadasa Bhikkhu got sick by having a hemorrhagic stroke. His disciples brought him to hospital for curing and invited to stay at monastery again until he passed away on Friday, $8^{\text {th }}$ July, 1993 at 11:20 a.m. at Suan Mokkhabalarama. He was eighty-seven years old while he was sixty-seven years of monkhood. His body was simply cremated according to testament. Formalin injections for preserving the body, requiring royal urn, and any funeral rites (Monks' Chanting) were rejected as he mentioned in testament. He only allowed ancient religious rites, for example placing coffin on a catafalque, holding four long sticks at the corner of coffin, and tying white cotton cloth with the tips of these sticks to be the ceiling of catafalque. For burning body Panyananda Bhikkhu or Phra Tepvisutthimedi in the honor rank name at that time who was the principal to light a fire.

\section{Natural Uposatha}

Next to this marble pillar is Uposatha (Church). It is outdoor space which is placed by white sands, covered by sky, and some trees as the pillars and wall. This is different from another Uposatha and this is what Buddhadasa Bhikkhu wants to be benefited to the monks for doing their functions. White sand ground of Uposatha divides into three layers. It can contain the monks more than one hundred. At the top of ground it has merely the white Buddha's statue in the attitude of subduing Mara (Evils) sitting in the center ground. The statue is placed on the altar and a halo of six colors is behind it. At the feet of altar appears the messages that 'for remembrance of half of century of Suan Mokkh in B.E. 2525 (A.D. 1982).' In addition, it has pillars to demarcate the land of Uposatha according to the Vinaya (rules) for construction.

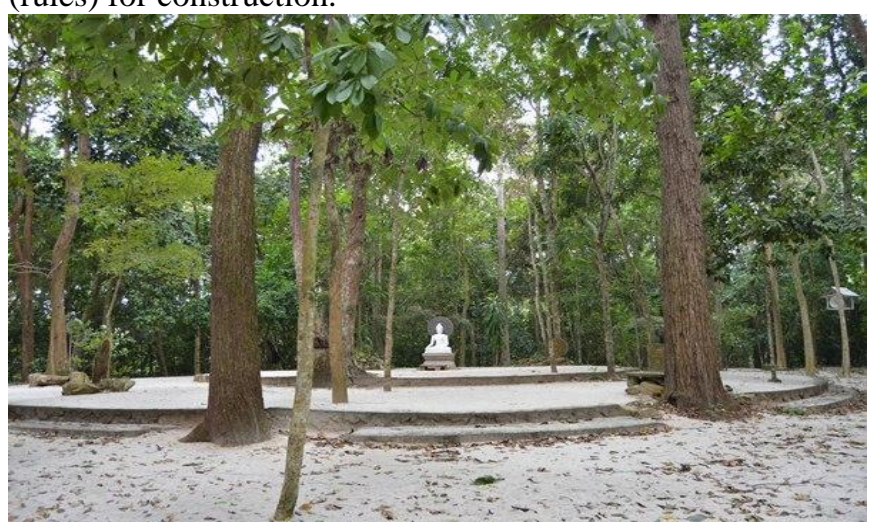

Fig. VI: Natural Uposatha [10]

The sign of monastery explains that 'it is the ground Uposatha along the nature like in Buddha's lifetime, around by the trees are wall, white clouds in the sky are ceiling, the treetops shaking along the wind are alive gable apexes. This place is for doing monks' services, considering all precepts, and candle light to walk clockwise proceedings. The lower ground is the place to burn Buddhadasa Khikkhu's body.'

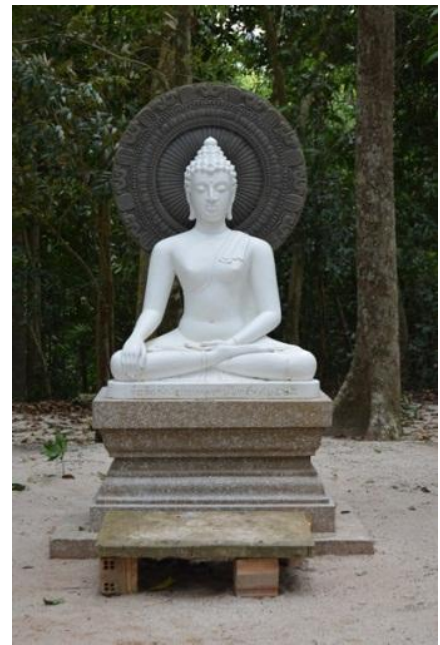

Fig. VII: White Buddha's Statue within Uposatha [11]

\section{Kuti Acariya Puja and Avalokiteshavara Bodhisattva's Statue}

If we walk down from Uposatha along another pathway, Kuti Acariya Puja (residence for paying respect to teacher) and Avalokiteshavara (Guanyin) Bodhisattva's Statue are on the right-hand side. Sala Dhamma Ghosana (Pavilion for propagating the Dhamma) is on the left-hand side. The Kuti Acariya Puja has Buddhadasa Bhikkhu's statue for worshiping inside. Next is Avalokiteshavara Bodhisattva's Statue which is established in the middle of greensward with messages explained that 'Buddhadasa Bhikkhu built this statue from original one which was an antique bronze. It was found in Chaiya City. It was a symbol of Suddhi (Purity), Paññā (Wisdom), Mettā (Loving-kindness), and Khanti (Tolerance). If you feel suffered or irritated by someone, 
you look at Avalokiteshavara's face and then it will make us feel comfortable.'

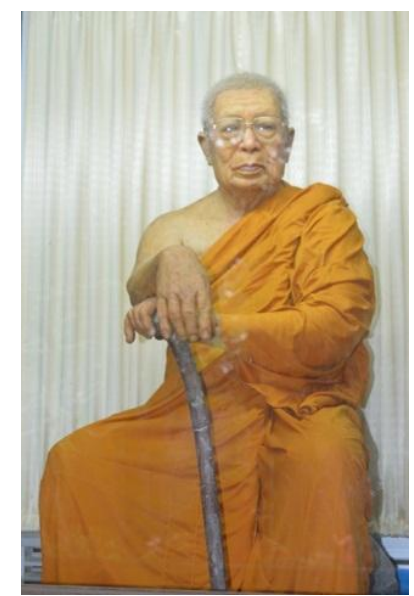

Fig. VIII: Buddhadasa Bhikkhu's Statue within Kuți Acariya Building [12]

Buddhadasa Bhikkhu defines the meaning of Bodhisattva that 'animal is that planting Bodhi tree which is wisdom for getting enlightened.' The important Dhamma of being Bodhisattva is called Bodhisattvadhamma or ideals of Bodhisattva, namely Suddhi, Paññā, Mettā, and Khanti. [13] 'Dhamma of Bodhisattva is of sacrificed and unselfish person. This is a real Bodhisattva who is preparing himself to become the Buddha, to destroy selfness and selfishness. When he gets rid of selfness, he will become the Arahanta, the Buddha.'

The reason that Buddhadasa Bhikkhu exhibits Bodhisattva's statue at monastery is that concerned with belief of Srivijaya Kingdom, the old kingdom of Chaiya city which believes in Mahayana Buddhism before. Also, his idea is strongly influenced by Zen Mahayana. Mahayana believes in Bodhisattva and practice goodness in order to become the Bodhisattva. Then, the basic concept of Mahayana emphasizes on Paññā and Mettā to help people escaping from sufferings more than finding the way like Theravada which emphasizes on the purity by escaping from sufferings himself first, then help people later.

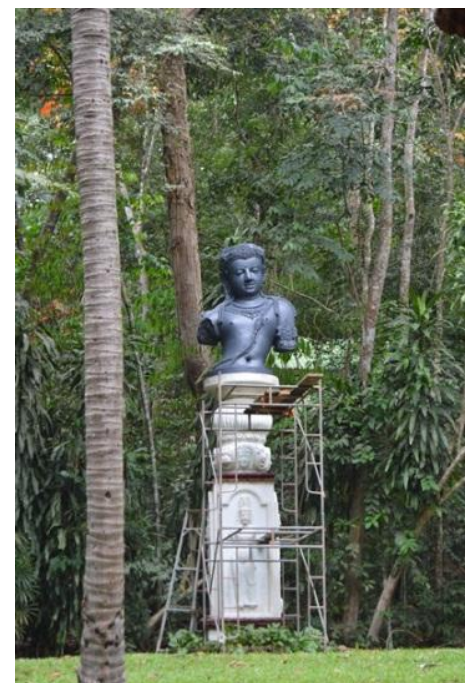

Fig. IX: Avalokiteshavara Bodhisattva’s Statue [14]

\section{Sala Dhamma Ghosana}

The opposite pathway of Kuti Acariya Puja is Sala Dhamma Ghosana which is located near the Curved Stone Court. The front of this building has Buddhadasa Bhikkhu's statue in standing position and inside is for collecting his works and bones. Due to his testament, it was specified to keep his own bones under pedestal of Buddha's statue which was plastered by cement. And his ashes were divided into three pots for floating and scattering at three places in Suratthani . Ajahn Bodhi Candasaro or Phra Khru Palad Srilawat, abbot of Wat Than Nam Lai (Suan Mokkh) at the time, who was leader to float and scatter the ashes at the following sites: 1) Chong Ang Thong: it was at $\mathrm{Mu}$ Ko Ang Thong National park, gulf of Thailand where has brought bricks to build Spiritual Theater at Suan Mokkh; 2) Khao Prasong: it was a steep mountain where has kept pot of his family's bones; and 3) Watercourse of Tapi river: it was within Khao Sok National Park.

Floating bones in river and scattering on mountain are concerned with Dhamma puzzle. It just signifies that body returns to the nature. It becomes to four elements, namely earth, water, fire, and wind. It is the way to learn Dhamma from the nature and a real normal life.

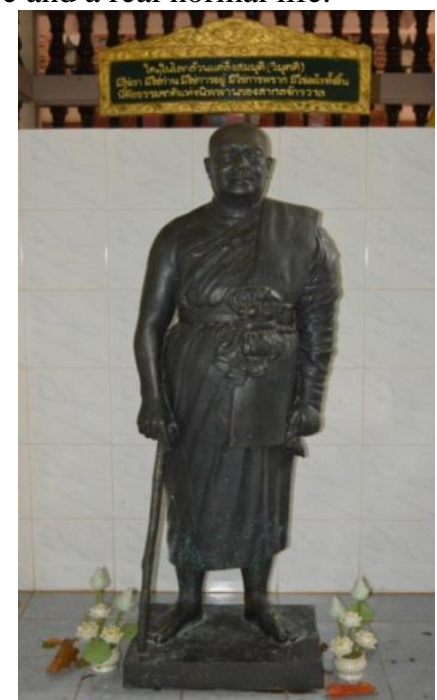

Fig. X: Buddhadasa Bhikkhu's Statue within Sala Dhamma Ghosana Pavilion [15]

\section{Hall for Meals and Nalike Pond}

If walking down form Bodhisattva's statue, it appears a hall for meals. Meal tables and chairs are constructed from cement as a long pedestal and almost fifty centimeters in height. Here, eating is a special and different from other because it has message that "where monks traditionally take their alms from a food-carrying cart while there is chanting by lay persons during the monks' meal.' 


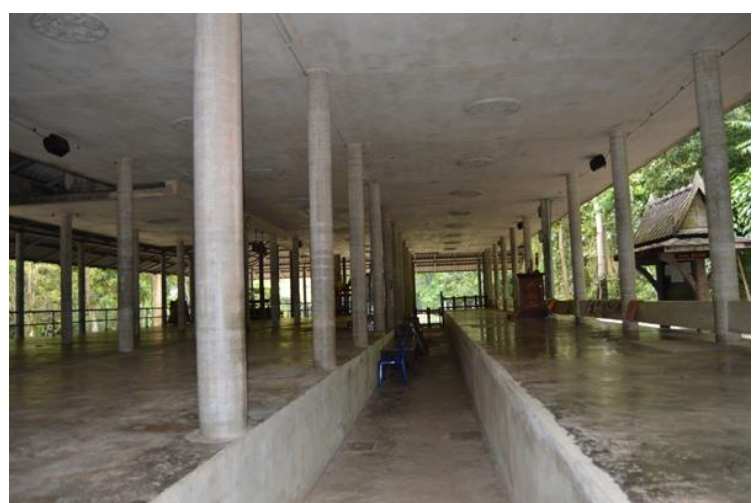

Fig. XI: A Hall for Meals [16]

Beside of the hall for meals it has a pathway to one of the important place at Suan Mokkh. Here is Nalike Pond which is in rectangle area and one hundred meter in width and two hundred meters in length. The pond is covered by algae. In the center it has a small island around five square meters where is overspread by grass. The sole coconut tree about twenty to thirty meters grows up there. It has an explanation that "there is a memorial of earnest Dhamma practice of grandparents in ancient time, in Thai old lullaby states that: Nalike coconut tree is lonely in the sea of beeswax. No rain, no thunder, stay in middle of sea of beeswax. It will be reached there by sage man only. The meaning is that Nibbana is present amidst samsara.'

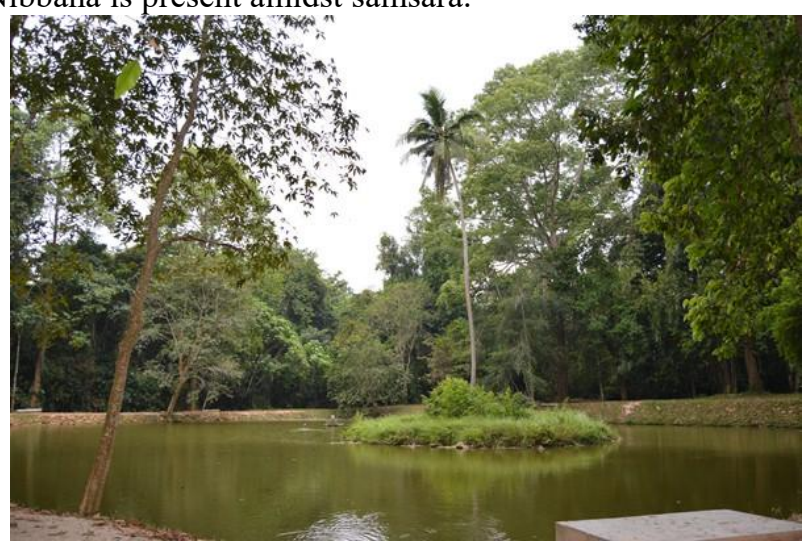

Fig. XII: Nalike Pond [17]

\section{Analytical Study of Zen on Buddhadasa Bhikkhu's Ideal}

As I mentioned above, it is able to analyze the concept of Zen which appears at Suan Mokkh as follows:

\section{Spiritual Theater}

In this case I mention to ten paintings of Emanuel Sherman, a Zen monk that Buddhadasa Bhikkhu duplicated and showed at the first floor of theater. These are called Koan for pondering to understand the real things that are hidden. The steps to ponder Koan are in the followings: first, trying to see what kind of that painting; second, considering carefully the real meaning of what does painting need to transmit; and third, attending the real meaning to our own minds, then that painting will shock us because it is teaching, blaming, and parodying us to change personality traits suddenly and it can get rid of defilements from our minds. [18] Sometimes people have to ponder Koan their whole life. The mind that cannot ponder Koan will despond and be tired. So, they have to communicate or ask a master to inspire themselves to ponder it. This method is called Mondo in Zen. When they penetrate Koan wisdom will occur brightly. Also, this theater is related to the Dhamma teaching heritage No. 7 and 9 of Buddhadasa Bhikkhu that he builds as essential materials to entertain the spirit of human beings. [19]

\section{Curved Stone Court}

This court looks like Zen garden which is one type of Japanese garden. This garden normally arranges at monastery. The components of this garden consist of sands, stones, and some trees. Especially, sands and stones represent the Buddha's teachings, i.e. sands mean the sea which is explained to Samsara or the cycle of birth and death and stones are explained as living beings which are in Samsara. In addition, this place is for demonstrating alms giving like the Buddha's lifetime according to the Dhamma teaching heritage No. 21. [20] This activity the people give alms into monks' bowls respectively while the monks are sitting and chanting.

\section{Natural Uposatha}

It is located at the top of hill called Khao Buddh Thong. It is most important place of monastery. Also, it reflects the concept of Zen like Curved Stone Court, but it is more meaningful place than Curved Stone Court. It is very quiet and calm because it is for monk's functions, such as ordination ceremony, chanting Uposatha (considering all precepts). This place looks like Zen garden called Dry Mountain-water Garden which is divided into two types: 1) Evergreen Garden and 2) Dry Landscape Garden. [21] Natural Uposatha seems like the second one. Sands and stones not only represent the Samsara and living beings in Samsara but also simplicity and minimalism to decorate the garden. This garden mostly appears somewhere at Zen monasteries or at the backside of abbot's room. It is comfortable to meditate and consider the Dhamma throughout balcony to the garden. While meditating they are able to ponder reality of life which is duplicated from these arts and architectures. [22] So, this garden is an abstraction of natural scenery to consider the Dhamma but Buddhadasa Bhikkhu applied it to use in daily life through Uposatha activities (ordination ceremony, considering all precepts) of Theravada sect.

\section{Dhamma Ships}

These look like the construction of ships which is the Buddha's teaching hidden. Also, it formally has Dry Landscape Garden on the top. The garden has many stone turtles representing the living beings in Samsara. Furthermore, in Japanese belief turtles refer to longevity which is meant that our lives in Samsara is too long until we reach the noblest goal, i.e. Nibbana. The bell tower is for ringing to assemble and remind to do activities. The upper floor of this tower has Sanchi pagoda that is duplicated from India. The tail part has a pavilion for Dhamma talk which is like a Zen abbot's room for meditating or considering the 
Dhamma throughout the garden. Therefore, Zen garden on Dhamma ship represents the Samsara which carries living beings on it. At the head of ship it has pagoda which is a symbol of Nibbana. And at the tail part it is a pavilion representing the mundane world of living beings which they have to swim cross the sea of Samsara (Zen garden) to the land of supramundane world.

\section{Avalokiteshavara Bodhisattva's Statue}

It is concerned with Mahayana belief since Srivijaya Kingdom. The reasons that Buddhadasa Bhikkhu built the statue can be assumed into two aspects as the followings: 1) old kingdom: in this area Srivijaya Kingdom, especially in Chaiya, a seaport of kingdom has ever grown up in the seventh to thirteenth centuries. And some periods of this kingdom believed in Mahayana. For this reason, Buddhadasa Bhikkhu might want disciples to study the growth of both kingdom and Mahayana in the ancient time. So, he decided to build the statue for reminding a new generation to study their own history as a center of Srivijaya Kingdom; 2) making a merit: Buddhadasa Bhikkhu might have the purpose to make a merit like Bodhisattva for helping people. So, he molded the statue for representing that purpose. Due to Determinations (Panidhana) of Buddhadasa Bhikkhu, there are three parts as followings: 1) it is to promote people to reach the heart of their own religion; 2) it is to withdraw human beings from materialism; 3) it is to understand clearly among religions. [23] These Determinations are in the Dhamma teaching heritage No. 2 to 5 of Buddhadasa Bhikkhu that he intends to do and everybody who needs to be Buddhadasa (Slave of the Buddha) should practice as the main roles for helping living beings. [24] Also these are concerned with Determinations of Mahayana which are divided into four parts in the followings: 1) I will help all loving beings to escape from sufferings; 2) I will get rid of defilements and help loving beings to get rid of; 3) I will study Dhamma and help loving beings to study; and 4) I will attain Buddhahood and help loving beings to attain. [25]

Concordance of the above Determinations (Panidhana) between Mahayana and Buddhadasa Bhikkhu is able to consider to Bodhisattvadhamma (Ideals of Bodhisattva) as following table:

\begin{tabular}{|c|c|c|c|}
\hline No. & $\begin{array}{l}\text { Mahayana's } \\
\text { Determinations }\end{array}$ & $\begin{array}{l}\text { Buddhadasa } \\
\text { Bhikkhu's } \\
\text { Determinations }\end{array}$ & $\begin{array}{l}\text { Bodhisattvadhamm } \\
\text { a }\end{array}$ \\
\hline 1 & $\begin{array}{l}\text { I will teach and } \\
\text { help all loving } \\
\text { beings to escape } \\
\text { from sufferings. }\end{array}$ & $\begin{array}{l}\text { To making } \\
\text { understand clearly } \\
\text { among religions. }\end{array}$ & $\begin{array}{l}\text { Mettā } \\
\text { kindness) }\end{array}$ \\
\hline 2 & $\begin{array}{l}\text { I will get rid of } \\
\text { defilements and } \\
\text { help loving beings } \\
\text { to get rid of. }\end{array}$ & $\begin{array}{l}\text { To promote people to } \\
\text { reach the heart of } \\
\text { their own religion. }\end{array}$ & Khanti (Tolerance) \\
\hline 3 & $\begin{array}{l}\text { I will study } \\
\text { Dhamma and help } \\
\text { loving beings to } \\
\text { study. }\end{array}$ & & Paññā (Wisdom) \\
\hline 4 & $\begin{array}{l}\text { I will attain } \\
\text { Buddhahood and } \\
\text { help loving beings } \\
\text { to attain. }\end{array}$ & $\begin{array}{lr}\text { To withdraw } & \text { human } \\
\text { beings } & \text { from } \\
\text { materialism. } & \end{array}$ & Suddhi (Purity) \\
\hline
\end{tabular}

Tab. I: Concordance of Determinations and

Bodhisattvadhamma
In the table it is explained that first Mahayana's Determination is associated with making understand clearly among religions and Mettā. This leads to be a true friend or friendship, work together with loving-kindness, compassion, etc. with any religions or other friends. Second and third one are associated with promoting people to reach the heart of their own religion and related with Khanti and Paññā. This leads to be patient people to do work until they get the wisdom to enlighten or attain Buddha nature which has in each person. In other religions they are able to reach the goal of their own religions. And the fourth is associated with withdrawing human beings from materialism and Suddhi (Purity). This leads to purify their minds, do not indulge in extreme way, especially in matters. Buddhadasa Bhikkhu thought about the Empty Mind which was meant to emptiness of attachment and did not attach about ' $I$ ' and 'Mine.'

Each Mahayana's Determination emphasizes on helping people which is important role of Mahayana sect. If it is thoroughly considered it is found that the four Mahayana's Determinations are able to compare with the Four Noble Truths in Theravada sect. [26] First, it is able to compare with Dukkha, means that comprehension (Pariñña) of the sufferings. Second, it is able to compare with Samudaya, means that eradication (Pahāna) of cravings which is the cause of sufferings. Third, it is able to compare with Magga, means that development or practice (Bhāvanā) for leading to cessation of sufferings. And forth, it is able to compare with Nirodha, means that realization (Sacchikiriyā) of cessation of sufferings.

\section{Nalike Pond}

It is the Dhamma teaching heritage No. 22 of Buddhadasa Bhikkhu [27] that he duplicates from Thai old lullaby and needs to commemorate people to maintain what ancestors taught in the ancient time. In Thai old lullaby it states that Nibbana is difficult to attain. People who have practiced enough can cross the sea of Samsara and reach the land of Nibbana. Coconut tree in the middle of a small island is like Nibbana which is within Samsara, but so far to reach this land. In Zen garden arrangement it is found that water and trees are component of garden. Buddhadasa Bhikkhu has hidden the Dhamma puzzles of Zen garden through building the pond and coconut tree which is related to Thai old lullaby. These are Koan which mixes between the Dhamma and local belief perfectly.

\section{Advantages of Studying Zen on Buddhadasa Bhikkhu's Ideal}

As mentioned above, Buddhadasa Bhikkhu's Ideal is included into two aspects in the followings: 1) living with nature; 2) working with empty mind.

The former one is concerned with religious buildings at Suan Mokkh. All things reflect on Buddhadasa Bhikkhu's practice which emphasizes on simplicity and cultivate the wisdom. In Dhamma teaching heritage No. 11 it is given to disciples which states on the "eating from cat bowl, bathing in a pond, sleeping in a pig stall, listening to mosquitos singing, etc.' these are to live simply without materialism and suitable to develop the mind through eating and living 
seem a low class but performing a high quality. [28] This means that human beings should survive simply, do not attach themselves to materialism, and live in harmony with nature, for example sitting on the ground of Uposatha, listening to the Dhamma around curved stone court. These are for living near nature and focusing on essentials of activity to understand the real purpose. This is able to apply to daily life, i.e. the four essential survivals (the Four Paccayas) that should associate with the nature.

The latter is concerned with the teaching of Empty Mind. This teaching reflects the teaching of Zen about Original Mind. The concept of this mind is influenced by Alaya Viñnāṇa of Yogācāra School and Suñnatā of Madhyāmika School in Mahāyāna sect. Zen received these concepts to apply for its own teaching and mixed with teachings of Taoism and Confucianism in China. After that it became a concept of Original Mind of Zen until now. In japan Zen was applied to Shintoism and became an important concept to develop Japanese cultures, such as garden arrangement, samurai, and tea ceremony. These cultures appear concept of empty mind or non-attachment in the background. For example samurai has to concentrate the mind on his sword while he is fencing off. When his mind is empty, calm down, and non-attached the mind is more liberated and powerful to train the way of warrior effectively. As mentioned above, it is able to apply for daily life which Buddhadasa Bhikkhu has ever taught about doing work with empty mind, discerning the world as emptiness, and living with emptiness according to the Dhamma teaching heritage No. 79. [29] And when doing work as responsibility, that responsibility is the Dhamma, so people are able to practice the Dhamma every day. [30]

\section{Conclusion}

Buddhadasa Bhikkhu is a change-oriented person, intellectual, master of meditation, and social reformer. He pays an important role in Theravada Buddhism since now. So, Donald K. Swearer who studied and translated Buddhadasa Bhikkhu's works in English entitles his name as Nagarjuna of Theravada. His works truly reflect the Buddhist society, do not support superstition, and avoid passionate materialism. Nowadays Buddhadasa Bhikkhu has been honored as one of the world's eminent personalities by the UNESCO. He is one of the important Buddhist philosophers. His works reflect Zen school not only what he established at Suan Mokkh but also his teachings about the empty mind, especially teaching of working with empty mind. According to the Dhamma teaching heritage No. 27, it is quoted that 'the trick of Zen is about the old methods in Buddhism which mixes Samatha and Vipassana to work together. It is to have Samadhi and careful consideration to attain original mind, i.e. reach non-defilements suddenly, do not separate methods because of the results of attachment. This rule is that Jhana is not for unwise person (No Paññā) and Paññā is not for non-contemplated person (No Jhana).' [31]
References

[1] Luangpu Dune Atulo. (2005). Gifts He Left behind: The Dhamma Legacy of Phra Ajaan Dune Atulo. Phra Bodhinandamuni, comp., Thanissaro Bhikkhu (Geoffrey DeGraff), trans. Valley Center: Metta Forest Monastery.

[2] Buddhadasa Bhikkhu. tran. (n.d.). The Zen Teaching of Huang Po. Bangkok: Thammasapa Publication.

[3] Wat Suan Mokkh International Dharmma Hermitage. Retrieved on 17th July, 2019 from http://gg.gg/nnjhh

[4] Phramaha Surachai Phutchu. (2016). Fieldwork at Suan Mokkhabalarama. On 7th February.

[5] Phramaha Surachai Phutchu, 2016.

[6] Chua, L. (2017). Contemporary Buddhist Architecture: From Reliquary to Theme Park, in the Oxford Handbook of Contemporary Buddhism. Jerryson, Michael, ed. New York: Oxford University Press. pp. 436-452.

[7] Buddhadasa Bhikkhu. (2009). Zen at Suan Mokkh. Bangkok: Thammasapa Publication.

[8] Buddhadasa Bhikkhu. (1974). Spiritual Theater at Suan Mokkhabalarama. Publishing for Donation on Cremation Ceremony of Wijit Meesaengnin. Bangkok: Kanpim Phranakhon Part., Ltd.

[9] Phramaha Surachai Phutchu, 2016.

[10] Buddhadasa Bhikkhu, n.d.

[11] Phramaha Surachai Phutchu, 2016.

[12] Boonsri, R. (2002). The Influence of Zen on Buddhadasa's Work. (Master's Thesis). Graduate School. Mahachulalongkornrajavidyalaya University.

[13] Buddhadasa Bhikkhu. (2013). Dhamma Teaching Heritages for Commemorating. Nonthaburi: Buddhist Prolonged Foundation of Wat Chonprathanrangsit. 
[14] Nitschke, G. (2007). Japanese Gardens: Right Angle and Natural Form. Koln: Taschen.

[15] Phramaha Surachai Phutchu. (2018). Zen Buddhism and Japanese Garden Arrangement. Japanese Studies Journal. 35(2), 14-26.

[16] Phra Dhamma Kosacariya (Prayoon Dhammacitto). (2006). Phra Dhamma Kosacariya (Buddhadasa Bhikkhu): The World's Eminent Personality. Bangkok: Propagation Organization of Wat Prayurawongsawat Worawihan.

[17] Buddhadasa Bhikkhu, 2013.

[18] Intasara, W. (2006). The Essential of Mahayana Buddhist Philosophy. 2nd ed. Bangkok: Dhammada.

[19] Poprasitsat, A. (1996). Mahayana Buddhism. 4th ed. Nakhon Pathom: Mahamakut Buddhist University Press.

[20] Buddhadasa Bhikkhu, 2013. 